\title{
Growth of the lower spleen pole remaining after subtotal splenectomy in rats ${ }^{1}$
}

\author{
O crescimento do pólo inferior remanescente da esplenectomia subtotal em ratos
}

\author{
Danilo Nagib Salomão PauloI, Bernardo Faria Ramos ${ }^{\mathrm{II}}$, Fernando Roberte Zanetti ${ }^{\mathrm{II}}$, Terezinha Marques ${ }^{\mathrm{III}}$, Luiz Cálice \\ Cintra $^{\text {IV }}$, Isabel Cristina Andreatta Lemos Paulov ${ }^{\text {, Alcino Lázaro da Silva }}{ }^{\text {I }}$ \\ ${ }^{\text {I }}$ Full Professor, Department of Surgery, EMESCAM, Vitória, Brazil.

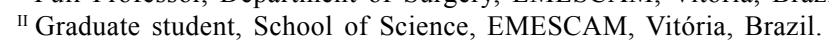 \\ III PhD, Physician of Pathology Center, Laboratory of Public Health of Espírito Santo, Vitória, Brazil. \\ IV Associate Professor, Department of Pathology, School of Science, EMESCAM, Vitória, Brazil. \\ v MS, Fellow PhD degree of Surgery, School of Medicine, Federal University of Minas Gerais (UFMG), Assistant Professor, Department of \\ Surgery, EMESCAM, Vitória, Brazil. \\ VI Professor Emeritus, Department of Surgery, School of Medicine, UFMG, Brazil.
}

\begin{abstract}
Purpose: To determine whether the lower pole of the spleen grows after subtotal splenectomy following ligature of major spleen blood vessels. Methods: Thirty-nine Wistar rats (328.8 $\pm 27.8 \mathrm{~g})$ submitted to subtotal splenectomy with preservation of the lower splenic pole were divided into two groups: group 1 (control, $n=20)$, immediate removal of the lower pole; group $2(n=19)$, removal of the pole on postoperative day 80 . The length, width and thickness of the pole were measured. In the control group, mean percent pole weight was calculated immediately after surgery in a direct and indirect manner. In the first case, the weight of the lower pole was divided by overall spleen weight; in the second case, pole weight was divided by the ideal weight of the spleen obtained by linear regression analysis. The results of the two calculations were compared. Macro- and microscopic examinations of the pole were performed. Results: In group 1, no significant difference in mean percent pole weight was observed between the direct and indirect method. In group 2, mean percent pole weight obtained by indirect calculation on day 80 was higher than in group $1(p<0.001)$. In group 2 , mean length, width and thickness of the pole remnant increased from the first to the $80^{\text {th }}$ day $(\mathrm{p}<0.05)$. Histological analysis showed preserved tissue architecture and features compatible with cell hyperplasia in group 2. Conclusion: The lower pole splenic remnant presented statistically significant growth up to postoperative day 80 after subtotal splenectomy, even after ligature of the major spleen vessels. Light microscopy revealed changes compatible with cell hyperplasia.
\end{abstract}

Key words: Spleen. Splenectomy. Rats.

\section{RESUMO}

Objetivo: Verificar se o pólo inferior do baço cresce após a esplenectomia subtotal mesmo com a ligadura dos vasos esplênicos principais. Métodos: 39 ratos, Wistar, pesando 328,8g $\pm 27,79$ foram submetidos à esplenectomia subtotal com preservação do pólo inferior e distribuídos em dois grupos de acordo com a época da retirada do referido pólo: 1- controle $(\mathrm{n}=20)$-retirada imediata; $2(\mathrm{n}=19)$; retirada no $80^{\circ}$ dia de pós-operatório. Foram medidos o comprimento, largura e espessura do pólo inferior. No grupo controle, o percentual médio do pólo inferior foi calculado imediatamente após a cirurgia de forma direta e indireta, e no grupo 2 de forma indireta. No cálculo direto dividiu-se o peso do pólo inferior pelo peso global do baço. No cálculo indireto dividiu-se o peso do pólo inferior pelo peso ideal do baço obtido por análise de regressão linear. Foi realizada a comparação entre esses dois cálculos. Foi realizado o exame macro e microscópico do pólo inferior. Resultados: Não houve diferença significante entre o cálculo direto e indireto do percentual médio do pólo inferior no grupo 1. No grupo 2 o percentual médio do pólo inferior, por cálculo indireto, no $80^{\circ}$ dia foi maior que no grupo 1 ( $\mathrm{p}<0,001$ ). A média do comprimento, largura e espessura desse remanescente no grupo 2 aumentou do $1^{\circ}$ para o $80^{\circ}$ dia $(\mathrm{p}<0,05)$. A análise histológica mostrou no grupo 2 manutenção da arquitetura esplênica e sinais compatíveis com hiperplasia celular. Conclusão: O pólo inferior do baço remanescente da esplenectomia subtotal, mesmo com a ligadura dos vasos esplênicos principais, apresentou média de crescimento significante no $80^{\circ}$ dia de pós-operatório e à microscopia óptica de luz houve sinais compatíveis com hiperplasia celular.

Descritores: Baço. Esplenectomia. Ratos.

1. Research performed at the Laboratory of the Division of Surgical Principles, Department of Surgery, School of Science, Santa Casa de Misericórdia, EMESCAM, Vitória, Brazil. 


\section{Introduction}

Complete removal of the spleen can cause local and systemic complications, ${ }^{1}$ the most serious being fulminant sepsis, which has been reported in five children with spherocytosis submitted to total splenectomy. ${ }^{2}$ Infectious complications after removal of the spleen have also been observed in experimental animals. ${ }^{3}$ Alterations in lipid metabolism following splenectomy have been reported in humans ${ }^{4}$ and experimental animals, ${ }^{5-8}$ which may provoke atherosclerosis. ${ }^{5}$ Therefore, total or partial spleen preservation is indicated whenever possible. Our group has described subtotal splenectomy with preservation of the lower pole even after ligature of major spleen blood vessels in dogs ${ }^{9}$ and rats. ${ }^{10}$ Analysis of lower pole function based on lipid metabolism in dogs showed an early decline on postoperative day 7 which, however, improved on postoperative day 60. ${ }^{11}$ This result led us to consider the possibility that morphological alterations of the pole occurred over time, improving spleen lipid metabolism. In a different model, subtotal splenectomy with preservation of the lower portion has shown its regeneration over time. ${ }^{12}$ This finding raised the question of whether this effect may also occur in a model of lower splenic pole preservation, ${ }^{10,11}$ which is characterized by ligature of the main trunks of the splenic vessels, permitting the pole to be supplied by vessels of the gastrosplenic ligament. The objective of the present study was to investigate the possible growth of the remaining lower spleen pole on the first and $80^{\text {th }}$ postoperative day after subtotal splenectomy and ligature of the major spleen vessels.

\section{Methods}

Animal manipulation was performed according to the recommendations for animal research of the Brazilian College of Animal Experimentation (Helsinki 1964) and subsequent versions (1975, 1983 and 1989). The study was approved by the Research Ethics Committee of the University of Minas Gerais, Brazil (ETIC 100/2006).

Thirty-nine Wistar rats $(328.8 \pm 27.8 \mathrm{~g})$ were submitted to subtotal splenectomy with preservation of the lower pole and divided into two groups according to the time of subsequent removal of the pole: group 1 (control, $\mathrm{n}=20)$, immediate removal; group $2(\mathrm{n}=19)$, removal on day 80 after subtotal splenectomy.

After a 12-hour fast, the animals were anesthetized by intramuscular injection of ketamine hydrochloride ( 50 $\mathrm{mg} / \mathrm{kg}$ weight) plus xylazine hydrochloride $(2.5 \mathrm{mg} / \mathrm{kg}$ weight) into the back of the right thigh. After shaving of the abdominal and thoracic ventral skin walls and antisepsis with polyvinylpyrrolidone-iodine, the animals were placed in the surgical field to delimit the laparotomy site. A $2.5-\mathrm{cm}$ longitudinal midline incision of the skin and subcutaneous tissue was initiated $0.5 \mathrm{~cm}$ below the xiphoid process towards the pubis, with opening of the linea alba and the peritoneum and examination of the peritoneal cavity. The upper and medial spleen was devascularized and sectioned for removal of the upper $2 / 3$ of the organ. The lower pole was kept irrigated by gastrosplenic ligament vessels according to Paulo et al. 9,10

The length, width and thickness of the pole were measured in its central part in the two groups with a pachymeter. After removal of the lower pole, animals of group 1 were sacrificed by administration of a lethal dose of sodium pentobarbital. Animals of group 2 were kept alive, their lower pole was measured, and the abdominal wall was closed at two levels with single 4.0 mononylon sutures: first the peritoneum and aponeurotic muscle and then the skin. After identification, the animals were returned to their cages (6/ cage). The bottom of each cage was covered with wood shavings and the roof consisted of metal grids. The rats were fed granular commercial animal chow (Primer MP Mill$77 \AA$, São Paulo, Brazil) and water ad libitum and received $200 \mathrm{mg}$ paracetamol dissolved in drinking water. Eighty days after surgery, animals of group 2 were anesthetized and submitted to laparotomy as described above. The lower poles were removed, measured and weighed, and the animals were injected with a lethal intraperitoneal dose of pentobarbital $(50 \mathrm{mg} / \mathrm{kg})$. The segment removed from the spleen and the remnant were weighed to a precision of 0.001 $\mathrm{g}$, examined macroscopically, photographed, fixed in buffered $4 \%$ formalin, and sectioned. Fragments were routinely processed for histological diagnosis of $3-\mu \mathrm{m}$ thick sections and stained with hematoxylin-eosin. Microscopy was performed by the same pathologist using a binocular microscope. Overall spleen architecture, capsule, white pulp (lymphoid follicles and their components), red pulp, vascularization and organ cellularity, as well as eventual inflammatory, degenerative and reparative processes, were evaluated.

\section{Statistical analysis}

a) Descriptive statistics was used for the calculation of arithmetic means and standard deviation of rat, spleen and lower pole weights. Percent weight was calculated by dividing lower pole weight by the respective total spleen weight and the mean percentage and standard deviation were calculated and called mean percent real pole weight (only for animals of group 1).

b) Linear regression analysis of mean percent weight of the remaining lower pole was performed by dividing the pole weight by the ideal spleen weight for each animal of group 1. For this purpose, the weight of the pole was divided by the ideal spleen weight for each animal of group 1 and the result was multiplied by 100 . The ideal spleen weight was calculated using the following formula: spleen weight $=1.80 \times$ body weight +230.49 , yielding the mean percent weight of the remaining spleen and its respective standard deviation, which was called mean percent ideal pole weight.

c) The t-test for related samples was used to compare pre- and postoperative weights in group 2 and to determine variations in the length, width and thickness of the lower pole from the first to the $80^{\text {th }}$ postoperative day.

d) The t-test for independent variables was used to compare weights between the two groups. This test was 
also used for comparison of the mean percent ideal weight and the mean percent real weight in animals of group 1.

All tests were two-tailed, and $\mathrm{p}$ values equal to or less than 0.05 were considered to be significant.

\section{Results}

Two animals died after surgery from an undefined cause. These animals were replaced with others of similar characteristics.

No significant difference in rat body weight was observed between the two groups ( $p>0.05)$. The weight of animals of group 2 increased significantly from the beginning to the end of the experiment. In group 1 , no difference between $\%$ mean real pole weight and $\%$ mean ideal pole weight was observed (Table 1). In group 2, \% ideal mean pole weight was significantly higher than that of group 1 (Table 1). The length, width and thickness of the lower pole increased after 80 days in group $2(p<0.05)$ (Table 2 ). In group 2 , a volume increase of the lower pole was observed in $68.4 \%$ of the animals, increasing the mean growth rate of the lower pole in this group $(\mathrm{p}<0.05)$.

TABLE 1 - Mean weight of the lower pole of rats submitted to subtotal splenectomy with preservation of the lower pole and ligature of major splenic vessels

\begin{tabular}{llccc}
\hline Group & \% RPW & \% IPW & p & p1 \\
$1(n=20)$ & $24.29 \pm 8.6$ & $25.98 \pm 10.4$ & NS & \\
$2(n=19)$ & & $51.8 \pm 30.76$ & & $<0.001$ \\
\hline
\end{tabular}

Results are reported as mean \pm standard deviation. Group 1: Rats submitted to subtotal splenectomy with immediate removal of the lower pole. Group 2: Rats submitted to subtotal splenectomy with removal of the lower pole after 80 days. \%RPW: Mean percent real weight of the lower pole calculated immediately after spleen removal. \%IPW: Mean percent ideal weight of the lower pole calculated by linear regression analysis. p: Student t-test for independent samples between \%RPW and \%IPW; p1: t-test for independent samples comparing \%IPW between groups 1 and 2. NS: not significant.

TABLE 2 - Lower spleen pole parameters on the first and $80^{\text {th }}$ postoperative day obtained for animals of group 2

\begin{tabular}{lrrr}
\hline Parameter & First day & Day 80 & $\mathrm{p}$ \\
Length & $1.15 \pm 0.23$ & $1.35 \pm 0.37$ & 0.0075 \\
Width & $0.78 \pm 0.18$ & $0.97 \pm 0.29$ & 0.019 \\
Thickness & $0.38 \pm 0.06$ & $0.50 \pm 0.20$ & 0.0171 \\
\hline
\end{tabular}

Results are reported as arithmetic mean \pm standard deviation. Ttest for related samples: $\mathrm{p}<0.05=$ significant.

Macroscopic analysis of the spleen revealed no marked alterations. Light microscopy analysis of pole fragments after 80 days showed a preserved cytoarchitectural structure in 16 rats $(84 \%)$ when compared to controls with a normal spleen and to group 2 itself (upper portion) (Figure 1a). Differentiation of the white and red pulp was considered to be satisfactory in $84 \%$ and $100 \%$ of the cases, respectively (Figure 1a). Spleen cellularity was abundant in $95 \%$ of the animals, with active germinative centers in $17(89.5 \%$ ) (Figure $1 b)$. In $68 \%$ of the cases, discrete thickening of the splenic capsule was noted (Figure 1c). Deposition of hemosiderin pigment (Figure 1c), but no necrosis or extracapsular fiber proliferation, was observed in all cases.

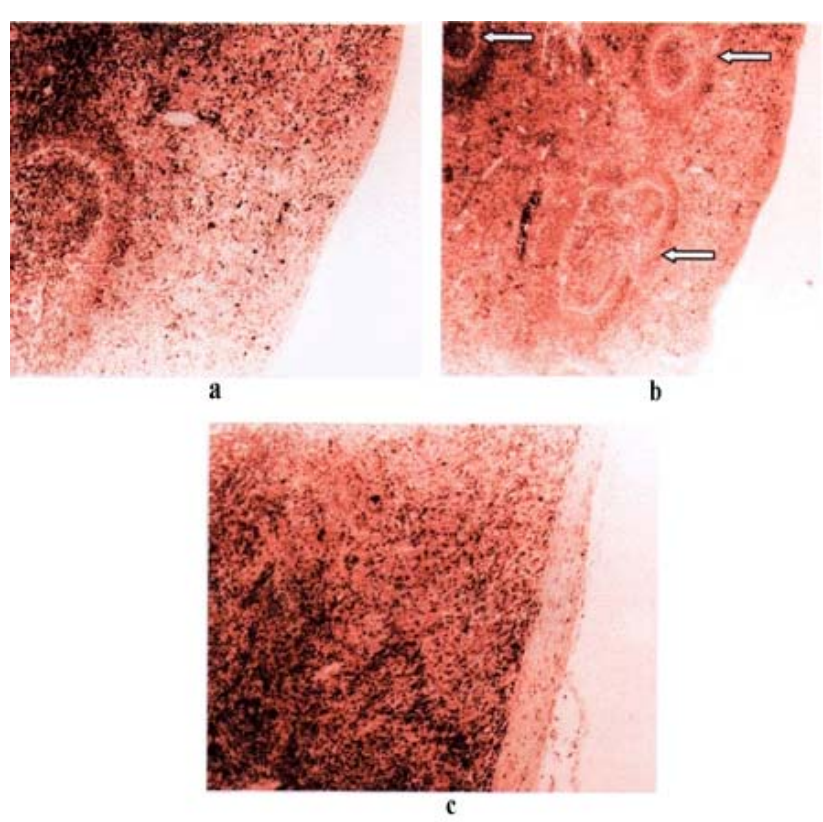

FIGURE 1 - a. Common microscopic aspect of the spleen showing good differentiation between the red and white pulp in controls. $\mathbf{b}$. Abundant cellularity in the spleen on day 80 after surgery. Note the highly active germinative centers (arrows). c. Mild thickening of the capsule on postoperative day 80

\section{Discussion}

The lower splenic pole of rats submitted to subtotal splenectomy and ligature of the major splenic vessels grew during the late postoperative period. The length, width and thickness of the remnant increased between the first and $80^{\text {th }}$ postoperative day in $68.4 \%$ of the animals, increasing the mean growth rate of the lower pole in animals of group $2(\mathrm{p}<0.05)$.

The mean weight of the lower pole was higher on day 80 compared to the control group $(p<0.05)$. Light microscopy revealed preservation of normal spleen architecture and signs compatible with cell hyperplasia.

Spleen remnant growth may have been due to growth of the animal, a traumatic inflammatory process, compensatory function of the spleen compromised by removal of its upper portion, or a combination of these factors. However, in the present study signs of an inflammatory process were insufficient to explain the phenomenon. An increase of lower pole weight at the 
expense of the growth of the animal could be ruled out since the calculation of percent growth of the lower pole was based on the ideal spleen weight as a function of the animal's weight obtained by linear regression analysis. Since this procedure was applied to both the control and 80-day groups and the mean percent ideal weight of the lower pole was significantly higher than in controls, it is plausible to relate pole growth to some sort of compensatory mechanism. On day 80 , the mean percent weight of the remaining poles of group 2 was $51.8 \%$, a value significantly higher $(\mathrm{p}<0.001)$ than the mean percent weight $(25.98 \%)$ observed for group 1 animals. This result might be explained by improved lipid metabolism as reported for dogs. ${ }^{11}$ In another experimental model, the lower pole was found to undergo a transformation which was interpreted as a regenerative process. ${ }^{12}$ Alternatively, considering that the lower pole may present a certain degree of immediate postoperative ischemia, ${ }^{10}$ ischemia may cause adherences ${ }^{13}$ that can develop along newly formed vessels. In the present study, upon removal on postoperative day 80 the lower pole was found to be frequently adhered to the omentum or abdominal wall; adherent vessels were frequently observed. It is therefore possible that these vessels contribute to the improvement of blood supply and function of the lower pole. It has been demonstrated that omentum applied to ischemic tissue induces angiogenesis, with probable involvement of adipocytes and vessel endothelial cells. ${ }^{14}$ The angiogenic capacity of the greater omentum has been demonstrated when the hepatic artery is connected during liver transplantation, followed by implantation of the greater omentum, ${ }^{15}$ or when fixed to the hepatic parenchyma after suppression of hepatic blood flow. ${ }^{16}$ Growth of the remaining lower splenic pole may thus be explained by the presence of blood vessels potentially capable of promoting this effect. Further investigations will be necessary to determine the role of angiogenesis using molecular biology methods and spleen stem cells in order to identify and understand the expression of proteins possibly involved in spleen growth. Lower pole growth, if confirmed in subsequent studies, would then provide the basis for a strong recommendation of this kind of conservative surgery in humans who require the functions of the spleen.

\section{Conclusion}

The remaining lower splenic pole presented significant growth on postoperative day 80 after subtotal splenectomy associated with ligature of the major spleen vessels, as demonstrated by light microscopy which showed features compatible with cell hyperplasia.

\section{References}

1. Petrovic M, Popovic M, Knezevic S, Matic S, Gotic M, Milovanovic A, Zuvela M, Artiko V, Dugalic V, Rankovic V. Intraoperative and postoperative complications of splenectomy. Acta Chir Iugosl. 2002; 49(3): 81-4.

2. King H, Shumacker Jr HB. Splenic studies. Ann Surg. 1952; 136: 239-42.

3. Andersson R, Alwmark A, Bengmark S. Outcome of pneumococcal challenge in rats after splenic artery ligation or splenectomy. Acta Chir Scand. 1986; 152: 15-7.

4. Aviram M, Brook JG, Tatarsky, Levy Y, Carter A. Increased low-density lipoprotein levels after splenectomy: a role for the spleen in cholesterol metabolism in myeloproliferative disorders. Am J Med Sci. 1986; 291: 25-8.

5. Asai K, Kuzuya M, Naito M, Funaki C, Kuzuya F. Effects of splenectomy on serum lipids and experimental atherosclerosis. Angiology. 1988; 39 : 497-504.

6. Silva MM, Jamel N, Refinetti RA, Oliveira MAS, Padilha MS. Papel do baço no perfil lipídico: Estudo Experimental. Arq Bras Cir Dig. 2002; 15: 121-4.

7. Paulo ICAL, Paulo DNS, Kalil M; Guerra AJ, Guerzet EA, Silva AL. Effects of two types of diet on plasma lipids in rats submitted to splenic surgery. Rev Assoc Med Bras. 2007; 53: 171-7

8. Petroianu A, Veloso DFM, Costa GR, Alberi LR. Effects of splenic surgeries on lipidograms of rats. Rev Assoc Med Bras. 2006; 52(1): 56-9.

9. Paulo DNS, Lázaro da Silva A, Cintra LC, BofAM, Santiago DC, Ribeiro GB. Esplenectomia subtotal, em cães, com preservação do pólo inferior suprido por vasos do ligamento gastroesplênico. Rev Col Bras Cir. 1999; 26: 147-52.

10. Paulo DNS, Paulo ICAL, Kalil M, Vargas PM, Lázaro da Silva A, Baptista JFA, Guerra AJ. Subtotal splenectomy preserving the lower pole in rats: technical, morphological and functional aspects. Acta Cir Bras. 2006; 21(5): 321-7.

11. Paulo DNS, Lázaro da Silva A. Lipídios plasmáticos após esplenectomia total e parcial em cães. Rev Col Bras Cir. 2001; 28: 264-70.

12. Torres OJM, Macedo EL, Picciani ERG, Nunes PMS, Costa JVG, Carvalho AB, Lobato Junior OS. Estudo histológico da regeneração esplênica de ratos submetidos à esplenectomia subtotal. Acta Cir Bras. 2000; 15(2): 1-12.

13. Ellis $\mathrm{H}$. The aetiology of post-operative abdominal adhesions. An experimental study. Br J Surg. 1962; 50: 10-6.

14. Goldsmith HS, Griffith AL, Kupferman A, Catsimpoolas N. Lipid angiogenic factor from omentum. J Am Med Assoc. 1984; 252(15): 203446.

15. Ishikawa M, Fjii M, Iuchi M, Miyaichi T, Tashiro S. Effect of intrahepatic omental implantation on angiogenesis in rat liver with hepatic artery ligation. Clin Exp Med. 2001; 1(1): 27-33. 
16. Silva PC, Jamel N, Refinetti RA, Manso EF, Schanaider A. Development of blood vessels of the greater omentum in the hepatic lobe after vascular ligation. An experimental model in the rats. Acta Cir Bras. 2006; 21(6): 416-21.

\section{Correspondence:}

Danilo Nagib Salomão Paulo

Rua Santa Rita de Cássia, 777

29042-753 Vitória-ES Brazil

Telephones: (55 27)3222-1545 / 3323-4827

danilo.vix@zaz.com.br
Conflict of interest: none Financial source: Solidarity Institute

Received: September 24, 2007

Review: November 23, 2007

Accepted: December 19, 2007

\section{How to cite this article}

Paulo DNS, Ramos BF, Zanetti FR, Marques T, Cintra LC, Paulo ICAL, Silva AL. Growth of the lower spleen pole remaining after subtotal splenectomy in rats. Acta Cir Bras. [serial on the Internet] 2008 Mar-Apr;23(2). Available from URL: http://www.scielo.br/acb 